\title{
The Efficiency of Nitrogen Fertilization of Spring Wheat Depending on Seasonal Rainfall
}

\author{
Edward Wilczewski ${ }^{{ }^{*}}$ \\ ${ }^{1}$ Department of Agrotechnology, Faculty of Agriculture and Biotechnology, University of \\ Technology and Life Sciences - UTP, 85-225 Bydgoszcz, Poland.
}

Author's contribution

The only author performed the whole research work, made the statistical analysis, wrote the first draft of the paper, read and approved the final manuscript.

Research Article

Received $15^{\text {th }}$ February 2013

Accepted $27^{\text {th }}$ April 2013

Published 10 ${ }^{\text {th }}$ May 2013

\section{ABSTRACT}

Aims: The main objective was to determine the influence of nitrogen fertilization on spring wheat grown after catch crops or without them.

Study Design: The split-plot experimental design with four replications was used.

Place and Duration of Study: A field experiments were carried out in the years 2005-2008 at Mochełek $\left(17^{\circ} 51^{\prime} \mathrm{E} ; 53^{\circ} 13^{\prime} \mathrm{N}\right)$ - an Experimental Station of the University of Technology and Life Sciences in Bydgoszcz.

Methodology: A two-factor, field experiment was conducted on Alfisols formed of a sandy loam in the north-central Poland. The $N$ rates were $\left[\mathrm{kg}^{\cdot h}{ }^{-1}\right]: 0,40,80,120,160$. The second factor was the catch crops - that were investigated - field pea (Pisum sativum var. arvense L.), oilseed radish (Raphanus sativus var. oleiformis L.), and a control without a catch crop. The main studied features were spring wheat yield and its components, depending on nitrogen rates. Moreover the most economic rate of nitrogen for spring wheat in years with different amount of rainfall were calculated.

Results: The optimal rate of nitrogen in spring wheat cultivation depended mainly on the total precipitation that prevailed during its growth. The highest grain yield of this plant grown after catch crops could be obtained applying 140-160 kg N.ha-1 in the year with a very good supply of rain water and $41-42 \mathrm{~kg} \mathrm{~N} \cdot \mathrm{ha}^{-1}$, in the extremely dry year.

The effect of catch crops on the yield of spring wheat depended on the rate of nitrogen. Very large increase in grain yield was obtained when no nitrogen was applied. After the 
application of 120 and $160 \mathrm{~kg} \mathrm{~N} \cdot \mathrm{ha}^{-1}$ there was no effect of catch crops on spring wheat productivity.

Conclusion: The most economic rate of nitrogen for spring wheat was lower than the agronomically optimal rate by about $30 \%$ in the year with a favourable rainfall distribution. In the extremely dry year, the nitrogen fertilization of spring wheat grown after catch crops was economically unjustified. The effect of catch crops on grain yield was positive only in spring wheat fertilized with nitrogen at a rate of up to $80 \mathrm{~kg} \cdot \mathrm{ha}^{-1}$.

Keywords: Efficiency; nitrogen fertilization; wheat; catch crop.

\section{INTRODUCTION}

Nitrogen is a major factor in wheat development, affecting the shoot numbers, spike length, and grain filling which determine grain yield [1] and its quality [2,3,4,5]. However, owing to the increasing prices of the energy needed for the production of $\mathrm{N}$ fertilizers, their cost is increasing [6]. Moreover, even a statistically significant increase in yield sometimes does not result in an improvement in crop profitability [7]. Therefore, the $\mathrm{N}$ application rate must be strictly adapted to the soil conditions and the availability of water for plants. This would obviously be very important in system where $\mathrm{N}$ applications are split into several applications and could be modified based on current growing season conditions. The optimum $\mathrm{N}$ fertilizer rate needed by a wheat crop to maximize profitability depends on the economic ratios of fertilizer costs, wheat grain values and the environmental conditions under which the crop is grown. Maximum profitability may be achieved at $\mathrm{N}$ rates $30 \%$ and even $90 \%$ less than those for maximum grain yields when growing conditions are normal or extremely dry, respectively. To determine the rate which is economically optimal, it is necessary to know the environmental conditions and the current relationship between fertilization costs and the value of wheat grain. The observed most economical rate of nitrogen (MERN) may will also be dependent upon the availability of other nutrients that may limit the responsiveness of the crop to applied fertilizer $\mathrm{N}$.

It is particularly essential to precisely determine the $\mathrm{N}$ rate for wheat grown on light soils prone to crop water deficits that could significantly impact the agronomic and economic effectiveness of the applied $\mathrm{N}$. The available water allows the plants to take up the applied nutrient elements and utilize them to produce a higher grain yield [3].

A valuable source of $\mathrm{N}$ and other nutrients for spring cereals can be the biomass of plants grown as a catch crop and plowed in the autumn of the previous year $[8,9]$. This allows for the improvement of the biological properties of soil $[8,10]$ and an increase in the grain yield of cereals grown after them. This is of particular importance in the current system of agricultural production, which is characterized by too high proportion of cereals in the cropping system. This may lead to a decrease in the organic matter in the soil and deterioration of biological soil condition. To prevent this unfavorable process, catch crops can be cultivated and the biomass produced used as a green manure. The plants which produce a high amount of organic matter and may positively influence the yield of succeeding crops and its quality (i.e. biomass, decomposability and nutrient content) are of particular value in achieving this goal. My previous research indicated that oilseed radish can produce a high yield of biomass and has a high ability to accumulate nutrients remaining in soil after the harvest of cereals [9]. Field pea is well known as a plant which has a positive 
influence on soil condition and the yield of succeeding crops. When grown as a catch crop and plowed in, it can significantly influence the yield of cereals [11].

The objective of the present research was to determine the influence of catch crops (oilseed radish and field pea) on the fertilizer $\mathrm{N}$ requirement of spring wheat.

\section{MATERIALS AND METHODS}

\subsection{Site and Weather Description}

Field experiments were conducted in 2005-2008 at the Mochelek ( $\left.17^{\circ} 51^{\prime} \mathrm{E} ; 53^{\circ} 13^{\prime} \mathrm{N}\right)$ - an Experimental Station of the University of Technology and Life Sciences in Bydgoszcz. A split-plot experimental design with four replications was used, where the whole plot treatments consisted of five $\mathrm{N}$ fertilizer rates and timings and the split-plot treatments consisted of two catch crops and control, without catch crop.

Nitrogen fertilization was the first experimental factor. Fertilizers were applied before and during the spring wheat growing period: the control (without $\mathrm{N}$ fertilization); $40 \mathrm{~kg}$ of $\mathrm{N}$ (before sowing); $80 \mathrm{~kg}$ of $\mathrm{N}$ (40 kg before sowing and $40 \mathrm{~kg}$ at the $\mathrm{BBCH} 31-32$ stage); 120 $\mathrm{kg} \mathrm{N}$ (60 kg before sowing and $60 \mathrm{~kg}$ at the $\mathrm{BBCH} 31-32$ stage); $160 \mathrm{~kg} \mathrm{~N}$ (60 kg before sowing, $60 \mathrm{~kg}$ at the $\mathrm{BBCH} 31-32$ stage and $40 \mathrm{~kg}$ at the $\mathrm{BBCH} 45-47$ stage). The second factor was the catch crops: field pea (Pisum sativum var. arvense L.); oilseed radish (Raphanus sativus var. oleiformis L.) and the control without a catch crop. The area of the plot was $30 \mathrm{~m}^{2}$.

The field experiment was carried out on Alfisols that was formed of a sandy loam [12]. The level of field water capacity at depths from 0 to $100 \mathrm{~cm}$ on this field range from 215 to 270 $\mathrm{mm}$ [13].

The analysis conducted according to Egner-Riehm method indicated, that the soil was abundant in available phosphorus (111 mg P per kg of dry soil) and potassium (367 mg K per $\mathrm{kg}$ of dry soil). Available magnesium content determined by atomic absorption spectrometry (AAS, Philips PU $9100 \mathrm{X}$ ) after extraction with $0.0125 \mathrm{M} \mathrm{CaCl}_{2}$, was on average level (60.5 mg Mg per $\mathrm{kg}$ of dry soil). The concentration of organic carbon $\left(\mathrm{C}_{\text {org }}\right)$, determined using the dichromate oxidation procedure, was $7.17 \mathrm{~g}$ per $\mathrm{kg}$ of dry soil. The total nitrogen concentration in the soil, determined according to Kjeldahl method amounted to $0.67 \mathrm{~g}$ per $\mathrm{kg}$ of dry mass. Soil $\mathrm{pH}$ in $1 \mathrm{M} \mathrm{KCl}$ was 6.47 .

\subsection{Plant Measurement and Analysis}

After the spring barley was harvested, the soil was plowed and cultivated using a cultivator with a crumbler roller. Catch crops were sown between August 3-11 in 2005-2007. After 7077 days of growth, the plants were mowed at a height of about $5-7 \mathrm{~cm}$ and the yield of green matter from each plot weighed. Subsequently samples of green matter (about $1 \mathrm{~kg}$ per plot) were taken to determine the dry matter yield. The rest of the green matter was returned to the plots and plowed in. The yield of post-harvest residue was determined based on samples collected from soil monoliths of $25 \times 25 \times 25 \mathrm{~cm}$, which were screened and rinsed with water. Each sample consisted of stubble and roots. 
Spring wheat (Triticum aestivum L.), 'Tybalt' cultivar, was sown between March 30 and April 11 in 2006-2008 in the stands where the biomass of the catch crop had been plowed under in order to evaluate its previous crop value. Each year, before the spring wheat was sown, mineral fertilization was applied. Phosphorus and potassium were broadcast at doses of $28.4 \mathrm{~kg} \mathrm{P} \cdot \mathrm{ha}^{-1}$ and $74.7 \mathrm{~kg} \mathrm{~K} \cdot \mathrm{ha}^{-1}$ and mixed with the soil using a cultivator with a crumbler roller.

Prior to harvest on each plot, the number of spikes and the number of grains per spike were determined. The number of spikes was counted on 2 randomly chosen rows, each $4.55 \mathrm{~m}$ long, which was equivalent to $1 \mathrm{~m}^{2}$. The number of grains per spike was determined based on 20 randomly chosen spikes from each plot. Spring wheat was harvested using a Wintersteiger plot harvester, during the period from August 1 to 8 . Grain samples were taken from each plot in order to determine its moisture and the 1000 grain weight. The grain collected from each plot were weighed and grain yield per ha was calculated and expressed on a $15 \%$ moisture content.

The weather conditions were analyzed based on measurements made at the local weather station located at the Experimental Station in Mochełek.

\subsection{Statistical Analysis}

Analysis of variance was done using the results obtained in individual years. The significance of differences was determined using Tukey's test at a 95\% level of confidence. In the case of grain yield, Student $T$ test was performed to compare pairs of independent samples i.e. yield obtained after field pea catch crop and $40 \mathrm{~kg} \mathrm{~N}$ per ha vs yield obtained in control without catch crop and $80 \mathrm{~kg}$ of $\mathrm{N}$ per ha.

The analysis of regression was made using the Statistica for Windows program StatSoft. The effectiveness of nitrogen fertilization $\left(\mathrm{N}_{\mathrm{Eff}}\right)$ was calculated separately for each interval rate $\left(0-40 ; 40-80 ; 80-120\right.$ and $\left.120-160 \mathrm{~kg} \mathrm{~N} \cdot \mathrm{ha}^{-1}\right)$. Calculations were done according to the equation:

$$
N_{E f f}=(\text { yield at } N X-\text { yield at } N X-40) / 40
$$

where suitable values for NX were $40,80,120$ and $160 \mathrm{~kg}$ and NX-40 were $0,40,80$ and 120 in order to calculate the efficiency of nitrogen fertilization for rate intervals: $0-40,40-80$, $80-120$ and 120-160, respectively. The yield of spring wheat grain is expressed in $\mathrm{kg}$ per ha and the calculated $N_{E f f}$ is expressed in $\mathrm{kg}$ of grain per $1 \mathrm{~kg}$ of $\mathrm{N}$ applied at this interval.

Yields for each treatment year combination were fitted to a quadratic model: $Y=a N^{2}+b N+c$, where $Y$ is wheat grain yield $\left(\mathrm{kg} \mathrm{ha}^{-1}\right), \mathrm{N}$ is the fertilizer $\mathrm{N}$ application rate $\left(\mathrm{kg} \mathrm{ha}^{-1}\right), \mathrm{ab}$ are regression coefficients $\mathrm{C}$ is the intercept. Taking the first derivative of the quadratic model (see Eq. 2) allows for the calculation of the slope (i.e. $d Y / d N$ ) at any selected value of $\mathrm{N}$.

$$
d Y / d N=2 a N+b
$$

Setting the slope to equal zero allows the calculation of the agronomically optimal rate of nitrogen $(A O R N)$, i.e. $0=2 a(A O R N)+b$, solving for $A O R N$ gives

$$
A O R N=-b / 2 a
$$


Similarly, setting the slope to equal the price ratio (PR) (i.e. ( $\$ / \mathrm{kg} \mathrm{N}) /(\$ / \mathrm{kg}$ grain)) allows for the calculation of most economic rate of nitrogen (MERN) [5], i.e. $P R=2 a(M E R N)+b$, solving for MERN gives

$$
M E R N=(P R-b) / 2 a
$$

The cost of $1 \mathrm{~kg}$ of nitrogen was assumed to be the market value of this element (4.30 PLN ${ }^{1}$ per $1 \mathrm{~kg})$ plus the cost of its application $(0.50 \mathrm{PLN})$. The price of $1 \mathrm{~kg}$ of wheat grain $(0.92$ PLN) was adopted following the Agricultural Advisory Centre (ODR) at Minikowo of 02.11.2012 [14]. The price ratio was 4.80:0.92 $=5.22$.

\section{RESULTS}

The water supply during the growing period of spring wheat was highly varied in the years of the study. In 2006, timely precipitation occurred during the critical plant growth stages of tillering and shooting, although the remainder of the growing season had significant moisture deficits (Table 1). In 2007 rainfall distribution was well adapted to the needs of spring wheat. Only a short-term deficiency of precipitation occurred in April. The water supply in the period from May to July was $48-97 \%$ higher than the average for the area of the study. In 2008 the weather conditions were extremely unfavourable for spring wheat. The total precipitation in May and June accounted for only $28.4 \%$ of the mean total precipitation for those months from that in the years 1949-2008.

Table 1. Total monthly precipitation on the research area [mm]

\begin{tabular}{lllll}
\hline Month & \multicolumn{3}{c}{ Year } & \multicolumn{3}{c}{ Mean for $\mathbf{1 9 4 9 - 2 0 0 8}$} \\
\cline { 2 - 5 } & $\mathbf{2 0 0 6}$ & $\mathbf{2 0 0 7}$ & $\mathbf{2 0 0 8}$ & \\
\hline March & 27.4 & 47.9 & 61.2 & 24.3 \\
April & 77.0 & 17.6 & 38.7 & 28.0 \\
May & 59.9 & 73.1 & 11.5 & 41.7 \\
June & 21.8 & 105.5 & 15.5 & 53.5 \\
July & 24.2 & 104.7 & 58.7 & 70.8 \\
Total III-VII & 210.3 & 348.8 & 185.6 & 218.3 \\
\hline
\end{tabular}

Nitrogen fertilization as well as catch crops had a significant effect on grain yield and on the yield structure components of spring wheat (Table 2). The effect of the nitrogen rate on the number of spikes and grain yield differed in the years of the study. In relation to the number of grains per spike and the 1000 grain weight, there was no interaction of the experimental factors with the years. Therefore, these features are presented in this paper in the form of means from the years for individual fertilization levels and catch crops. Due to the significant interaction between the experimental factors and the years in relation to grain yield, the results concerning this variable are presented both as the means from 2006-2008 and for individual years.

${ }^{1}$ Polish Zloty; 1 PLN =0.31 USD (http://www. money.pl/ 02.11.2012 
Table 2. F-values and significance levels from an analysis of the variance of main spring wheat traits

\begin{tabular}{|c|c|c|c|c|c|c|}
\hline \multirow{2}{*}{$\begin{array}{l}\text { Traits of spring } \\
\text { wheat }\end{array}$} & \multicolumn{2}{|l|}{ Factors } & \multicolumn{4}{|c|}{ Interactions } \\
\hline & $\begin{array}{l}\text { I -Rate } \\
\text { of } N^{\&} \\
\text { (d.f.=4) }\end{array}$ & 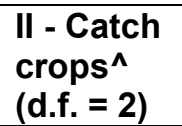 & $\begin{array}{l}I x \text { II } \\
\text { (d.f.=8) }\end{array}$ & $\begin{array}{l}\mathrm{IX} \\
\text { Years } \\
\text { (d.f.=8) }\end{array}$ & $\begin{array}{l}\text { II X } \\
\text { Years } \\
\text { (d.f.=4) }\end{array}$ & $\begin{array}{l}\text { I x II x } \\
\text { Years } \\
\text { (d.f.=16) }\end{array}$ \\
\hline Number of spikes & $8.068^{* * *}$ & $6.46^{* *}$ & $0.42 \mathrm{~ns}$ & $8.17^{\star * *}$ & $0.32 \mathrm{~ns}$ & $0.31 \mathrm{~ns}$ \\
\hline $\begin{array}{l}\text { Number of grains } \\
\text { per spike }\end{array}$ & $6.01^{* * *}$ & $11.66^{\star * \star}$ & $1.51 \mathrm{~ns}$ & $0.90 \mathrm{~ns}$ & $0.67 \mathrm{~ns}$ & $0.71 \mathrm{~ns}$ \\
\hline 1000 grain weight & $3.31^{*}$ & $7.64^{* * *}$ & $0.50 \mathrm{~ns}$ & $1.57 \mathrm{~ns}$ & $2.47 \mathrm{~ns}$ & $1.10 \mathrm{~ns}$ \\
\hline Grain yield & $59.31^{* * *}$ & $93.68^{* * *}$ & $10.53^{* * *}$ & $48.31^{\star * *}$ & $15.27^{\star * *}$ & $2.23^{* * *}$ \\
\hline
\end{tabular}

\subsection{Yield of Plants Grown as a Catch Crop}

The yield of field pea and oilseed radish in the present study was at an average level for the experimental region (Table 3). The highest yields of plant dry matter were obtained in 2006 and 2007 and the lowest in 2005. Although the dry matter yield of field pea was significantly higher than that of oilseed radish, the mean post-harvest residue yield of field pea from 2005-2007 was significantly lower than that of oilseed radish.

Table 3. Dry matter yield of catch crops plowed in the autumn [Mg:ha-1]

\begin{tabular}{|c|c|c|c|c|c|}
\hline \multirow{2}{*}{ Part of plant } & \multirow{2}{*}{$\begin{array}{l}\text { Plant } \\
\text { species }\end{array}$} & \multicolumn{3}{|c|}{ Year } & \multirow{2}{*}{$\begin{array}{l}\text { Means for } \\
2005-2007\end{array}$} \\
\hline & & 2005 & 2006 & 2007 & \\
\hline \multirow[t]{2}{*}{ Green matter } & $\mathrm{FP}^{*}$ & $1.07 a^{\#}$ & $3.07 \mathrm{a}$ & $2.90 \mathrm{a}$ & $2.35 a$ \\
\hline & OR & $0.64 \mathrm{~b}$ & $0.92 \mathrm{~b}$ & $1.48 b$ & $1.01 \mathrm{~b}$ \\
\hline \multirow{2}{*}{$\begin{array}{l}\text { Post-harvest } \\
\text { residue }\end{array}$} & FP & 1.27 & $0.80 \mathrm{~b}$ & 1.10 & $1.06 \mathrm{~b}$ \\
\hline & OR & 1.10 & $1.89 a$ & 1.04 & $1.34 \mathrm{a}$ \\
\hline \multirow{2}{*}{$\begin{array}{l}\text { Total dry } \\
\text { matter }\end{array}$} & FP & $2.34 \mathrm{a}$ & $3.87 \mathrm{a}$ & $4.00 \mathrm{a}$ & $3.41 \mathrm{a}$ \\
\hline & OR & $1.74 \mathrm{~b}$ & $2.81 \mathrm{~b}$ & $2.52 \mathrm{~b}$ & $2.35 \mathrm{~b}$ \\
\hline
\end{tabular}

\subsection{Spring Wheat Yield Components}

Experimental factors had an effect on the features determining wheat yield (Table 4, Figs. 1 and 2). The nitrogen rate significantly modified the number of spikes of spring wheat in the years 2006-2008, which was the largest after the application of $40 \mathrm{~kg} \cdot \mathrm{ha}^{-1}$, and significantly smaller for treatments that were not fertilized with nitrogen or that were fertilized with a very high rate of this element $\left(160 \mathrm{~kg} \cdot \mathrm{ha}^{-1}\right)$. The effect of nitrogen on the number of spikes differed in individual years. In 2006 the number of spikes was only significantly greater than the $0 \mathrm{~kg} \mathrm{~N} \cdot \mathrm{ha}^{-1}$ after the application of 120 or $160 \mathrm{~kg} \mathrm{~N} \cdot \mathrm{ha}^{-1}$. In 2007 it was enough to apply $40 \mathrm{~kg} \mathrm{~N} \cdot \mathrm{ha}^{-1}$ to obtain the maximal number of spikes. In 2008 spring wheat fertilized with nitrogen at a rate of $40 \mathrm{~kg}^{\cdot h^{-1}}$ also formed significantly more spikes than the wheat that was 
not fertilized and increasing the rate of this element to 120 and $160 \mathrm{~kg} \cdot \mathrm{ha}^{-1}$ led to a significant decrease in the number of spikes.

Table 4. The number of spring wheat spikes per $\mathrm{m}^{2}$

\begin{tabular}{|c|c|c|c|c|c|}
\hline \multirow[t]{2}{*}{ Factors } & & \multicolumn{4}{|l|}{ Year } \\
\hline & & 2006 & 2007 & 2008 & $2006-2008$ \\
\hline \multirow{5}{*}{$\begin{array}{l}\text { Nitrogen fertilization } \\
{\left[\mathrm{kg} \cdot \mathrm{ha}^{-1}\right]}\end{array}$} & 0 & $520 b^{\#}$ & $431 \mathrm{~b}$ & $280 \mathrm{~b}$ & $410 \mathrm{c}$ \\
\hline & 40 & $556 a b$ & $512 a$ & $363 a$ & $477 \mathrm{a}$ \\
\hline & 80 & $572 a b$ & $521 a$ & $291 a b$ & $461 \mathrm{ab}$ \\
\hline & 120 & $588 a$ & $523 a$ & $250 \mathrm{bc}$ & $454 a b$ \\
\hline & 160 & $591 \mathrm{a}$ & $514 a$ & $198 \mathrm{c}$ & $434 \mathrm{bc}$ \\
\hline \multirow[t]{3}{*}{ Catch crop } & $\mathrm{FP}^{*}$ & 574 & 507 & 283 & $455 a$ \\
\hline & OR & 571 & 505 & 276 & $451 \mathrm{a}$ \\
\hline & C & 551 & 489 & 270 & $436 \mathrm{~b}$ \\
\hline
\end{tabular}

Both plants grown as a catch crop for green manure exerted a significant, positive effect on the number of spikes of spring wheat from the years 2006-2008. The impact of this factor was not significant in individual years.

Fertilization with nitrogen had a significant effect on the number of grains in the spring wheat spikes (Fig. 1). These were the highest after the application of 80,120 or $160 \mathrm{~kg} \mathrm{~N} \cdot \mathrm{ha}^{-1}$ and significantly lower in wheat not fertilized with this element.

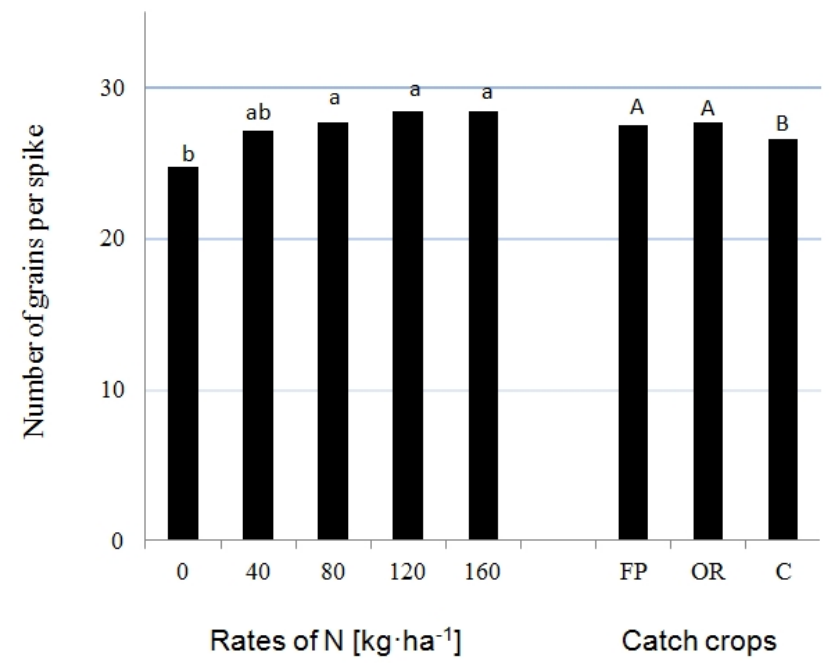

Fig. 1. The number of grains per spike of spring wheat as affected by $\mathrm{N}$-fertilization and catch crops plowed as a green manure in the autumn of previous year - means for 2006-2008

FP - field pea, OR - oilseed radish, $C$ - control (means marked with the same small or the same capital letters do not differ significantly at $\alpha=0.05$ ) 
Field pea and oilseed radish grown as a catch crop resulted in a significant increase in the number of grains per spike. No interaction was found between the experimental factors and years in relation to this feature.

The factors of the experiment significantly affected the 1000 grain weight (Fig. 2). On the treatments where $160 \mathrm{~kg} \mathrm{~N} \cdot \mathrm{ha}^{-1}$ was applied, it was significantly larger than in the control without nitrogen fertilization. The catch crops plowed in the autumn also contributed to a significant increase in the 1000 grain weight of spring wheat relative to the control.

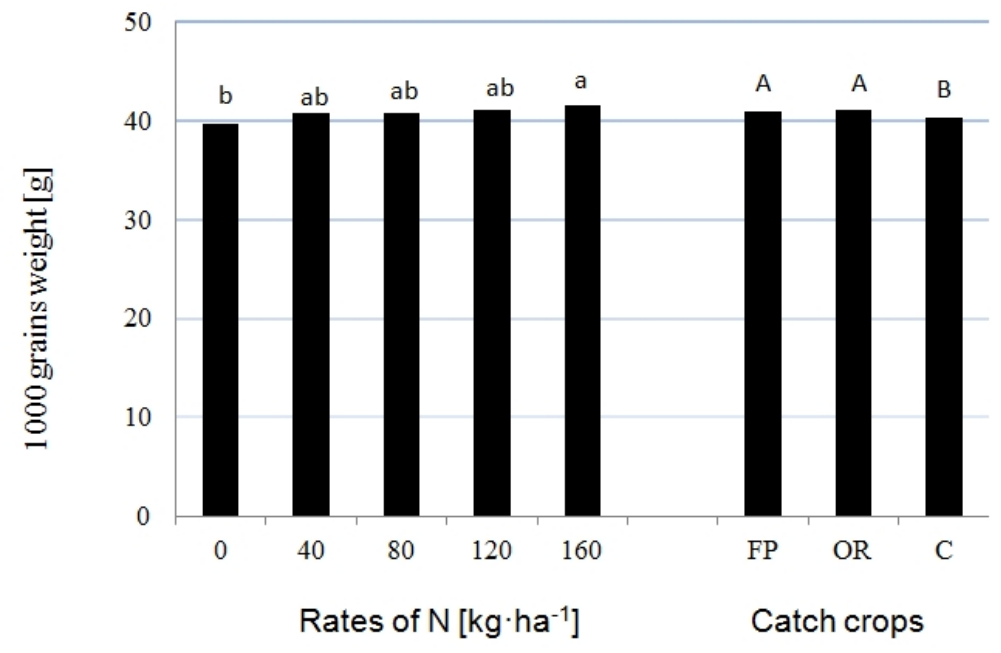

Fig. 2. The weight of 1000 grains of spring wheat [g] as affected by $\mathrm{N}$-fertilization and catch crops plowed as a green manure - means for 2006-2008

FP - field pea, OR - oilseed radish, C - control (means marked with the same small or the same capital letters do not differ significantly at $\alpha=0.05$ )

\subsection{Spring Wheat Grain Yield}

The spring wheat grain yield was significantly dependent on both experimental factors (Table 5). On average in the three-year period of the study, the most favourable rate was $80 \mathrm{~kg}$ $\mathrm{N} \cdot \mathrm{ha}^{-1}$, which had a significantly higher yield than the application of $40 \mathrm{~kg} \mathrm{~N} \cdot \mathrm{ha}^{-1}$. The lowest wheat yield was obtained on treatments where nitrogen was not applied. Increasing the nitrogen rate to a level of $80 \mathrm{~kg} \cdot \mathrm{ha}^{-1}$ resulted in a significant increase in grain yield both on treatments where wheat was grown after catch crops and in the control without catch crops. Wheat grown after catch crops and fertilized with a rate of $40 \mathrm{~kg} \mathrm{~N} \cdot \mathrm{ha}^{-1}$ gave the same yield as the control after the application of $80 \mathrm{~kg} \mathrm{~N} \cdot \mathrm{ha}^{-1}$. Increasing nitrogen fertilization from 80 to $120 \mathrm{~kg} \mathrm{ha}^{-1}$ resulted in a significant decrease in the grain yield of spring wheat grown after catch crops. 
Table 5. Grain yield of spring wheat $\left[\mathrm{Mg}^{\cdot} \mathrm{ha}^{-1}\right]$, depending on nitrogen fertilization and biomass of catch crops plowed as a green manure - means for 2006-2008

\begin{tabular}{|c|c|c|c|c|}
\hline \multirow{2}{*}{$\begin{array}{l}\text { Nitrogen fertilization } \\
{\left[\mathrm{kg}^{\left.-\mathrm{ha}^{-1}\right]}\right.}\end{array}$} & \multicolumn{4}{|c|}{ Catch crop } \\
\hline & FP* & OR & C & Mean \\
\hline 0 & $2.41 \mathrm{cA}^{\#}$ & $2.44 \mathrm{cA}$ & $2.11 \mathrm{cB}$ & $2.32 \mathrm{c}$ \\
\hline 40 & $2.96 \mathrm{bA}$ & $3.02 \mathrm{abA}$ & $2.75 \mathrm{bB}$ & $2.91 \mathrm{~b}$ \\
\hline 80 & $3.14 \mathrm{aA}$ & $3.19 \mathrm{aA}$ & $3.01 \mathrm{aB}$ & $3.12 \mathrm{a}$ \\
\hline 120 & $2.95 \mathrm{~b}$ & $2.98 \mathrm{~b}$ & $2.91 \mathrm{ab}$ & $2.95 a b$ \\
\hline 160 & $2.97 \mathrm{ab}$ & $2.98 \mathrm{~b}$ & $2.95 \mathrm{a}$ & $2.97 \mathrm{ab}$ \\
\hline Mean & $2.89 \mathrm{~A}$ & $2.92 \mathrm{~A}$ & $2.74 \mathrm{~B}$ & 2.85 \\
\hline
\end{tabular}

Field pea and oilseed radish grown as catch crops for green manure caused a significant increase in the grain yield of spring wheat. The effect of catch crops on the yield of spring wheat depended on the rate of nitrogen. Wheat not fertilized with nitrogen responded with very large increases in grain yield $(14.3 \%$ after pea and $15.5 \%$ after radish). After the application of $40 \mathrm{~kg} \mathrm{~N} \cdot \mathrm{ha}^{-1}$, the increase in yield amounted to 7.8 and $10.0 \%$, respectively. Wheat fertilized with nitrogen at a rate of $80 \mathrm{~kg} \cdot \mathrm{ha}^{-1}$ also had significantly increased grain yield under the influence of catch crops. After the application of 120 and $160 \mathrm{~kg} \mathrm{~N} \cdot \mathrm{ha}^{-1}$ there was no effect of catch crops on spring wheat productivity. The response of spring wheat to fertilization with nitrogen differed in individual years of the study. The second degree polynomial regression analysis indicates that the agronomically optimal rate of nitrogen (AORN) in 2007 amounted to $139-161 \mathrm{~kg} \cdot \mathrm{ha}^{-1}$ after catch crops and $174 \mathrm{~kg}^{-\mathrm{ha}^{-1}}$ in control treatment (Table 6). In 2008 it was only $41-42 \mathrm{~kg} \cdot \mathrm{ha}^{-1}$ and $51 \mathrm{~kg} \cdot \mathrm{ha}^{-1}$ respectively.

The analysis of fertilization profitability determined based on the regression equations and price ratio showed a different effectiveness of this factor in individual years (Table 6). At the current price relation of nitrogen to wheat (5.22:1), the MERN for spring wheat were lower than the AORN by $24.1-35.2 \%$ in the year with a good (2007) or moderately favourable rainfall distribution (2006). In the extremely dry year (2008) an increase in nitrogen rates above $12 \mathrm{~kg}^{\cdot h^{-1}}$ in control treatment caused a decrease in profitability. The fertilization of spring wheat grown after field pea catch crop in this year was economically unjustified.

The effectiveness of nitrogen fertilization $\left(\mathrm{N}_{\mathrm{Eff}}\right)$ within the range of 0 to $40 \mathrm{~kg} \cdot \mathrm{ha}^{-1}$ was high in all of the years of the study (Fig. 3). The average increase in grain yield per $1 \mathrm{~kg}$ of nitrogen applied ranged from $12.4 \mathrm{~kg}$ in 2008 to $17.0 \mathrm{~kg}$ in 2007 . The effectiveness of higher nitrogen rates was much different in the years of the study. In 2006 a small positive effect was found in the range of 40 to 80 and of 80 to $120 \mathrm{~kg} \cdot \mathrm{ha}^{-1}$. Increasing the rate from 120 to $160 \mathrm{~kg} \cdot \mathrm{ha}^{-1}$ resulted in a decrease in grain yield by $4.4 \mathrm{~kg}$ on average per each $\mathrm{kg}$ of the applied nitrogen. In 2007 a relatively high effectiveness of nitrogen was obtained within the range of 40 to $80 \mathrm{~kg} \cdot \mathrm{ha}^{-1}$. The effectiveness of nitrogen fertilization in the range of 80 to $120 \mathrm{~kg}^{\cdot \mathrm{ha}^{-1}}$ was from -1.63 for wheat grown after radish to 1.93 for wheat grown in the control without a catch crop. In 2008 the effectiveness in all of the studied ranges of rates above $40 \mathrm{~kg}^{\mathrm{ha}}{ }^{-1}$ was less than zero. 
Table 6. Regression equations and yield of spring wheat at agronomically optimal rates of nitrogen (AORN) and the most economical rates of nitrogen (MERN)

\begin{tabular}{|c|c|c|c|c|c|c|c|}
\hline Year & $\begin{array}{l}\text { Catch } \\
\text { crop }\end{array}$ & Regression equation & $\begin{array}{l}\text { Regression } \\
\text { coefficient }\end{array}$ & $\begin{array}{l}\text { AORN } \\
{\left[\mathrm{kg}^{\left.-\mathrm{ha}^{-1}\right]}\right.}\end{array}$ & $\begin{array}{l}\text { Yield at AORN } \\
{\left[\mathrm{Mg}^{\left.-\mathrm{ha}^{-1}\right]}\right.}\end{array}$ & $\begin{array}{l}\text { MERN }^{\&} \\
{\left[\mathrm{~kg}^{\left.-\mathrm{ha}^{-1}\right]}\right.}\end{array}$ & $\begin{array}{l}\text { Yield at MERN } \\
{\left[\mathrm{Mg} \cdot \mathrm{ha}^{-1}\right]}\end{array}$ \\
\hline \multirow[t]{3}{*}{2006} & $\mathrm{FP}^{*}$ & $y=-0.073 N^{2}+15.2 N+2043$ & 0.905 & 104 & 2.84 & 68 & 2.74 \\
\hline & OR & $y=-0.068 N^{2}+14.7 N+2018$ & 0.895 & 108 & 2.81 & 70 & 2.71 \\
\hline & C & $y=-0.081 N^{2}+19.0 N+1670$ & 0.952 & 117 & 2.78 & 85 & 2.70 \\
\hline \multirow[t]{3}{*}{2007} & $\mathrm{FP}^{*}$ & $y=-0.060 N^{2}+19.3 N+3066$ & 0.920 & 161 & 4.62 & 117 & 4.50 \\
\hline & OR & $y=-0.076 N^{2}+21.2 N+3112$ & 0.892 & 139 & 4.61 & 105 & 4.50 \\
\hline & C & $y=-0.062 N^{2}+21.6 N+2636$ & 0.941 & 174 & 4.52 & 132 & 4.41 \\
\hline \multirow[t]{3}{*}{2008} & $\mathrm{FP}^{*}$ & $y=-0.059 N^{2}+4.8 N+2261$ & 0.738 & 41 & 2.36 & 0 & 2.26 \\
\hline & OR & $y=-0.066 N^{2}+5.6 N+2331$ & 0.780 & 42 & 2.45 & 3 & 2.36 \\
\hline & $\mathrm{C}$ & $y=-0.068 N^{2}+6.9 N+2142$ & 0.795 & 51 & 2.32 & 12 & 2.22 \\
\hline
\end{tabular}

${ }^{*} \mathrm{FP}$ - field pea, OR - oilseed radish, $\mathrm{C}$ - control

\# - regression equation calculated based on grain yields from plots expressed as $\mathrm{kg}$ per ha

${ }^{\&}$ the values were calculated for the ratio of cost of $1 \mathrm{~kg}$ of $N$ to price of $1 \mathrm{~kg}$ of grain: 5.22:1.00 
American Journal of Experimental Agriculture, 3(3): 579-594, 2013

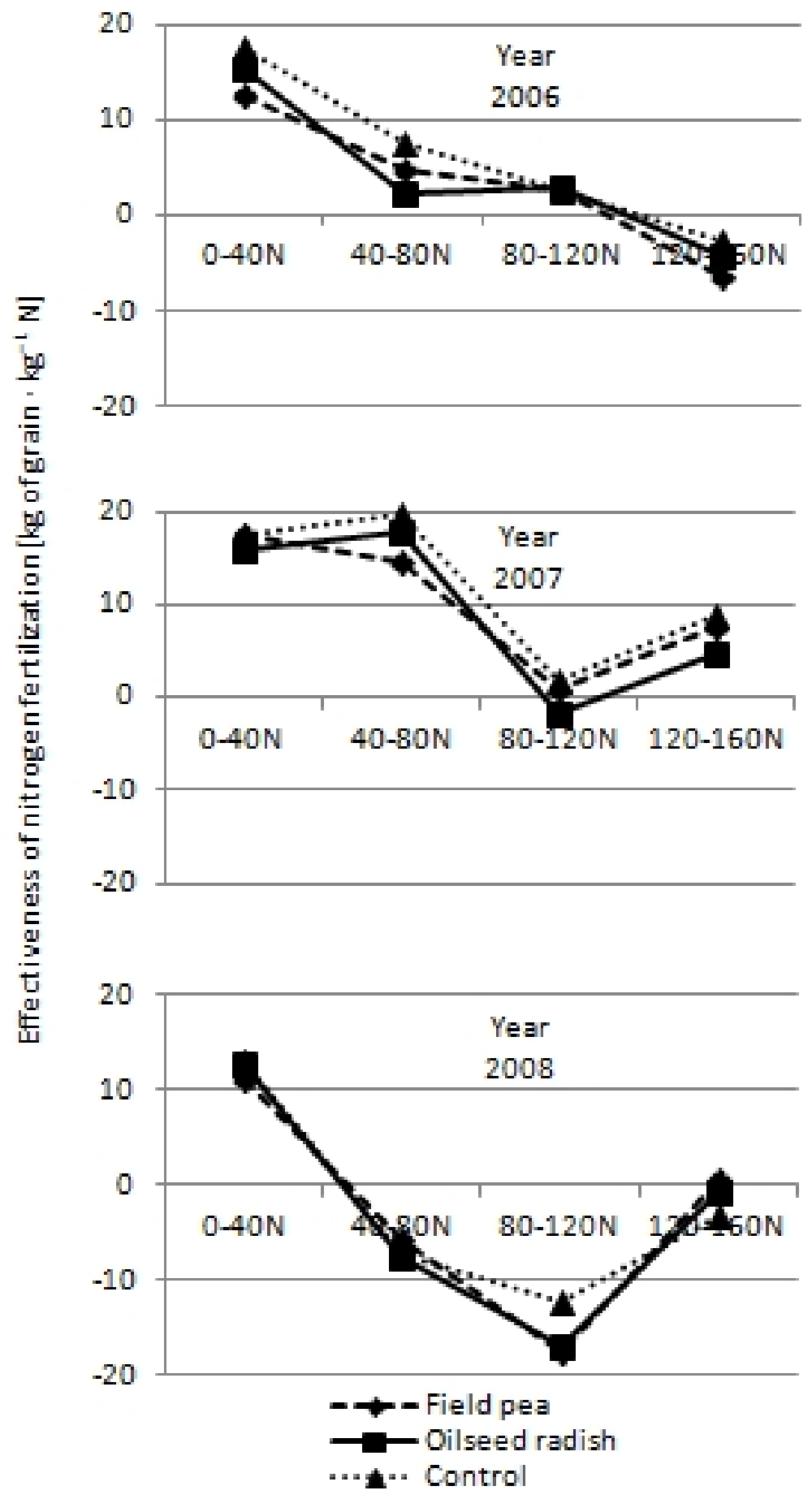

Fig. 3. Effectiveness of nitrogen fertilization $\left(\mathrm{N}_{\mathrm{Eff}}\right)$ of spring wheat grown after catch crops (field pea, oilseed radish) or without them (control), measured separately in particular rate intervals ( $\mathrm{kg}$ of grain yield increase $\cdot \mathbf{k g}^{-1} \mathrm{~N}$ rate increase) 
In all of the years of the study, there was a correlation between grain yield and the number of spikes of spring wheat (Table 7). The number of grains per spike and the 1000 grain weight were positively correlated with grain yield only in the years with a good or moderate water supply (2007 and 2006).

Table 7. Correlation coefficients between grain yield and the yield components of spring wheat $(n=15)$

\begin{tabular}{llll}
\hline Yield components & \multicolumn{2}{l}{ Grain yield } & \\
\cline { 2 - 4 } & $\mathbf{2 0 0 6}$ & $\mathbf{2 0 0 7}$ & $\mathbf{2 0 0 8}$ \\
\hline Number of spike per $\mathrm{m}^{2}$ & $0.92^{*}$ & $0.85^{*}$ & $0.92^{*}$ \\
Number of grains per spike & $0.92^{*}$ & $0.88^{*}$ & 0.34 \\
Weight of 1000 grains & $0.65^{*}$ & $0.78^{*}$ & 0.09 \\
\hline
\end{tabular}

\section{DISCUSSION}

\subsection{Yield of Plants Grown as a Catch Crop}

The green matter yield of plants grown as a catch crop depends mainly on the supply of water and fertilizer elements. Under conditions of a favourable distribution of precipitation, good soil fertility and nitrogen fertilization applied at a rate of $60-90 \mathrm{~kg}^{-\mathrm{ha}^{-1}}$ it ranges from 3 to $6 \mathrm{Mg} \mathrm{ha}^{-1}[8,15,16]$. In general, plants of the family Fabaceae give lower yields than oilseed radish. In the present study, field pea formed a significantly higher yield of green matter and total biomass than oilseed radish. The reason for the poor yield of radish could be the relatively low soil abundance of nitrogen. This element is taken up by radish in very large amounts, often exceeding $160 \mathrm{~kg}^{\mathrm{h} h \mathrm{H}^{-1}}$ [16]. When grown in soil that is not abundant in nitrogen and under conditions where there is a lack of fertilizing catch crops containing this element, radish cannot form as large a yield as pea.

\subsection{Grain Yield of Spring Wheat and its Structure}

The average grain yield of spring wheat from the 3 years of the study was very low $(2.85$ $\left.\mathrm{Mg} \cdot \mathrm{ha}^{-1}\right)$. This was a result of both the unfavourable weather conditions that prevailed in 2 out of the 3 years of the study and from the sandy-loamy soil that was not very productive on which the wheat was grown.

A positive effect of nitrogen fertilization on all the wheat yield components confirms the need for splitting its application into three rates. This is indicated by the effect of nitrogen fertilization on the 1000 grain weight of wheat. Increasing the $N$ rate by as much as 120 $\mathrm{kg} \cdot \mathrm{ha}^{-1}$ did not affect this feature. Only after the application of $160 \mathrm{~kg}$ it was significantly higher than in the control. This effect results from the way of division of the highest nitrogen rate. The third part of this rate $\left(40 \mathrm{~kg} \cdot \mathrm{ha}^{-1}\right)$ applied directly before wheat earing caused formation of better filled grain. Splitting into two equal parts spread before sowing and at the beginning of shooting stage, rates 80 and $120 \mathrm{~kg}^{\cdot h^{-1}}$ had no effect on 1000 grain weight. $A$ positive effect of nitrogen applied before earing on the 1000 grain weight was obtained in 2007, characterized by a favourable rainfall distribution during spring wheat growing period. This effect was not observed in the other years. Thus in years that are characterized by rainfall deficit in this period the application of this rate is ineffective. According to Engel et al. [1] and Boaretto et al. [17] the air temperature is also of utmost importance for the yield- 
forming influence of nitrogen applied at later development stages. Under conditions of very high temperatures the period of grain filling is shortened, leading to a decrease in 1000 grain weight and the yield. A negative effect of high temperatures on wheat yield was observed even under conditions of a high amount of precipitation. In the present study, in 2 of 3 years air temperatures in the period of grain filling were considerably higher than the long-term averages, which combined with rainfall deficit led to formation of poorly filled grain.

Field pea and oilseed radish grown as a catch crop for green manure exerted a positive effect on the grain yield of spring wheat. This positive effect resulted mainly from an increase in the number of spikes and the number of grains per spike. The 1000 grain weight was also dependent on catch crops, but an increase in the value of this feature under the influence of plowed biomass was only $1.5-1.7 \%$.

The results of research presented in the literature concerning the impact of catch crops on the yield of succeeding crops are ambiguous. Many studies have shown negative effects $[18,19,20]$ or no impact of catch crops plowed under on the yield of cereals [21]. In order to obtain the desired effect, it is necessary to select the appropriate plant species for growing as a catch crop.

The results of current research indicate that legumes grown as catch crops and plowed in autumn have a favorable effect on spring cereals. Their biomass in soil undergoes fast mineralization and the nutrients that are released are taken up by cereals growing under these conditions. The positive, successive impact of these catch crops is possible if they produce a high yield of biomass. This is dependent mainly on the moisture conditions that occur during July and August $[22,23]$. Non-legume plants are less sensitive to the sowing date and weather conditions during growth. However, their impact on the yield of cereals grown after them is often much weaker. The results obtained confirm previous studies which suggest that oilseed radish grown in catch crops and used for green manure makes a significant improvement in the yield and grain quality of cereals [21].

\subsection{Effectiveness of Spring Wheat Fertilization with Nitrogen}

The rainfall deficiencies that occurred during the present study had a very strong impact on the effectiveness of nitrogen fertilization and on the values of individual yield structure elements. The least favorable weather conditions that prevailed in 2008 at the stages of shooting, earing and flowering resulted in very weak spike formation. The maximal grain

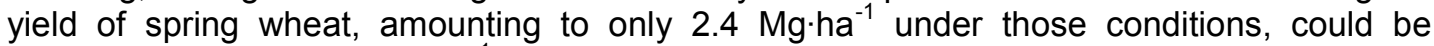
obtained using 41-51 kg N.ha-1. Applying nitrogen in such conditions was less profitable. In 2007, when the water supply was favourable throughout the growing period, the yield obtained was almost two times higher and the AORN was 3.5 times higher. These results confirm the well-known importance of nitrogen fertilization in yield formation, particularly under conditions where there is a good water supply $[1,24]$. The obtained results confirm the necessity of flexible nitrogen fertilization. The rate of nitrogen applied pre-plant should not exceed $40-50 \mathrm{~kg}^{-h^{-1}}$ particularly in lighter soils with poorer water retention. Such a rate is highly effective in respect of productivity, irrespective of the weather conditions during growth. The effectiveness of higher rates is determined by a good supply of water throughout the development period of spring wheat. The study by Boaretto et al. [17] indicates that the main part of nitrogen fertilization should be applied during the period of tillering. This ensures the maximal uptake of nitrogen by plants and minimal losses of this element from the soil. A negative aspect of top-dressing with nitrogen is the risk of its poor effectiveness under conditions of rainfall deficiency [4,25]. Since the total precipitation and 
its distribution while carrying out the present study was usually unfavourable, the effectiveness of nitrogen fertilization in the present study was very low within the range of 40 to $160 \mathrm{~kg} \cdot \mathrm{ha}^{-1}$ and was also different in individual years. Under those conditions, increasing the nitrogen rate from 80 to $120 \mathrm{~kg} \cdot \mathrm{ha}^{-1}$ did not result in an increase in the grain yield of spring wheat or even led to its decreasing. In a study conducted under more favourable soil and weather conditions [2], the optimal nitrogen rate for spring wheat was $120 \mathrm{~kg} \cdot \mathrm{ha}^{-1}$. In the present study, even in the year with a good water supply, no improvement of spring wheat yield was observed as a result of increasing the nitrogen rate from 80 to $120 \mathrm{~kg} \cdot \mathrm{ha}^{-1}$. This probably resulted from conducting the study on less favourable soil conditions.

The large differences in the economic effectiveness in the years of the study, which resulted from extremely different supplies of rain water to plants, are typical for light soils. Under such conditions, a growth in yield that can compensate for the incurred costs of fertilizers is possible only in years with an optimal rainfall distribution or by applying irrigation [1].

\section{CONCLUSION}

The optimal rate of nitrogen in spring wheat production depended mainly on the total precipitation that prevailed during its growth. The MERN for spring wheat at the current price ratio of nitrogen to wheat (5.22:1) was lower than the AORN by $24.1-35.2 \%$ in the year with a favourable rainfall distribution. In the extremely dry year, $\mathrm{N}$ fertilization in spring wheat grown after field pea was economically unjustified and in the control (without catch crops) it was hardly profitable.

Field pea and oilseed radish grown as a catch crop and plowed in for green manure resulted in a significant increase in the grain yield of spring wheat. The positive effect of catch crops decreased along with an increase in the nitrogen rate. This effect was very strong in spring wheat unfertilized with nitrogen or after the application of $40 \mathrm{~kg} \mathrm{~N} \cdot \mathrm{ha}^{-1}$, and significant after the application of $80 \mathrm{~kg} \mathrm{~N} \cdot \mathrm{ha}^{-1}$, whereas it did not occur under conditions of fertilization with higher rates of nitrogen.

\section{COMPETING INTERESTS}

Author has declared that no competing interests exist.

\section{REFERENCES}

1. Engel R, Long D, Carlson G. Nitrogen requirements and yield potential of spring wheat as affected by water. Fertilizer Facts. 2001;25.

2. Gauer LE, Grant CA, Gehl DT, Bailey LD. Effects of nitrogen fertilization on grain protein content, nitrogen uptake, and nitrogen use efficiency of six spring wheat (Triticum aestivum L.) cultivars, in relation to estimated moisture supply. Can. J. Plant Sci. 1992;72:235-241.

3. Walley F, Pennock D, Solohub M, Hnatowich G. Spring wheat (Triticum aestivum) yield and grain protein responses to $\mathrm{N}$ fertilizer in topographically defined landscape positions. Can. J. Soil Sci. 2001;81:505-514.

4. Karamanos RE, Flore NA, Harapiak JT. Effect of post-emergence nitrogen application on the yield and protein content of wheat. Can. J. Plant Sci. 2005;85:327-342. 
5. Denys CJ, O'Halloran IP, Lauzon JD. Effect of nitrogen fertilization and topography on soft red winter wheat yield and protein content in two Ontario landscapes. Can. J. Soil Sci. 2006;86:729-739.

6. Raun WR, Solie JB, Johnson GV, Stone ML, Mullen RW, Freeman KW, Thomason WE, Lukina EV. Improving nitrogen use efficiency in cereal grain production with optical sensing and variable rate application. Agron. J. 2002;94:815-820.

7. Rakowski D. Effect of sprinkling irrigation and mineral fertilisation on yielding of some spring wheat and spring triticale cultivars on light soil. Part I. Grain yield. Acta Sci. Pol., Agricultura. 2003;2(2):19-31. Polish.

8. Thorup-Kristensen $\mathrm{K}$. The effect of nitrogen catch crop species on the nitrogen nutrition of succeeding crops. Fertil. Res. 1994;37:227-234.

9. Wilczewski E. Utilization of nitrogen and other macroelements by non-papilionaceous plants cultivated in stubble intercrop. Ecological Chemistry and Engineering. 2010;17(6):689-698.

10. Piotrowska A, Wilczewski E. Effects of catch crops cultivated for green manure and mineral nitrogen fertilization on soil enzyme activities and chemical properties. Geoderma. 2012;189-190:72-80.

11. Jaskulski D, Tomalak S, Rudnicki F. Regeneration of the stand after winter wheat for spring barley with catch crop plants. Zesz. Probl. Post. Nauk Roln. 2000;470:49-57. Polish.

12. Soil Survey Staff. Keys to Soil Taxonomy, $11^{\text {th }}$ ed., Washington, DC: USDA Natural Resources Conservation Service; 2010.

13. Rolbiecki St, Rolbiecki R, Rzekanowski C, Żarski J. The influence of sprinkler irrigation on yields of some vegetable crops in the region of Bydgoszcz, Poland. Acta Horticulturae. 2000;537:871-877.

14. Anonymous. K-PODR: Quotation system. Minikowo: Agricultural Advisory Centre, 2012. Available: http://www.ceny.kpodr.pl; Polish.

15. Eichler B, Zachow B, Bartsch S, Koppen D, Schnug E. Influence of catch cropping on nitrate contents in soil and soil solution. Landbauforschung Völkenrode, 2004;54:7-12.

16. Wilczewski E, Lemańczyk G, Skinder Z, Sadowski Cz. Effect of nitrogen fertilization on the yielding and health status of selected non-papilionaceous plant species grown in stubble intercrop. EJPAU, Ser. Agron. 2006;9(2):04.

17. Boaretto AE, Cantarella H, de Freitas JG, Spolidoirio ES, Trivelin PCO, Muraoka T. Optimizing nitrogen fertilizer application to wheat under irrigation. In: Optimizing nitrogen fertilizer application to irrigated wheat. Results of a co-ordinated research project organized by the Joint FAO/IAEA Division of Nuclear Techniques in Food and Agriculture. 2000;63-72.

18. Kankanen $\mathrm{H}$. The effect of undersown clover and grass on the nitrogen leaching risk during autumn and winter, [in:] The use of catch or cover crops to reduce leaching and erosion (ed. B. Linden). NFJ - rapport (Finland), 1995;99:79-86.

19. Richards IR, Wallace PA, Turner IDS. A comparision of six cover crop types in terms of nitrogen uptake and effect on response to nitrogen by a subsequent spring barley crop. J. Agric. Sci., 1996;127:441-449.

20. Thorsted MD, Olesen JE, Koefoed N. Effects of white clover cultivars on biomass and yield in oat/clover intercrops. J. Agric. Sci. 2002;138:261-267.

21. Skinder Z, Wilczewski E. Forecrop value of non-papilionaceous plants cultivated in stubble intercrop for spring barley under various fertilisation conditions. EJPAU, Ser. Agronomy. 2004;7(1):\#03.

22. Vos J, van der Putten PEL. Field observation on nitrogen catch crops. I. Potential and actual growth and nitrogen accumulation in relation to sewing date and crop species. Plant Soil. 1997;195:299-309. 
23. Wilczewski E, Skinder Z, Szczepanek M. Effect of weather conditions on yield of tansy phacelia and common sunflower grown as stubble catch crop. Pol. J. Environ. Stud. 2012;21:1053-1060.

24. Sepaskhah AR, Hosseini SN. Effects of Alternate Furrow Irrigation and Nitrogen Application Rates on Yield and Water- and Nitrogen-Use Efficiency of Winter Wheat (Triticum aestivum L.). Plant Prod. Sci. 2008;11:250-259.

25. Matson PA, Naylor R, Ortiz-Monasterio I. Integration of environmental, agronomic and economic aspects of fertilizer management. Science. 1998;280:112-115.

(c) 2013 Wilczewski; This is an Open Access article distributed under the terms of the Creative Commons Attribution License (http://creativecommons.org/licenses/by/3.0), which permits unrestricted use, distribution, and reproduction in any medium, provided the original work is properly cited.

Peer-review history:

The peer review history for this paper can be accessed here:

http://www.sciencedomain.org/review-history.php?iid=229\&id=2\&aid=1372 